\title{
RESEARCH ON MONITORING THE WETLAND LANDCOVER CHANGE BASED ON THE MODERATE RESOLUTION REMOTE SENSING IMAGE
}

\author{
Mo Zhou ${ }^{\mathrm{a}}$, Xiaohong Yuan ${ }^{\mathrm{b}}$, Limei Sun ${ }^{\mathrm{a}}$ \\ ${ }^{a}$ Heilongjiang Geomatics Center of SBSM, 32Cehui Road, Nangang Dist., Harbin, China - zhoumo@hljbsm.gov.cn \\ ${ }^{\mathrm{b}}$ Heilongjiang Bureau of Survery and Mapping, 32Cehui Road, Nangang Dist., Harbin, China - yxh@hljbsm.gov.cn
}

KEY WORDS: Information Extraction, Object Oriented, Statistical Analysis, Landcover, Zhalong wetland reserve

\begin{abstract}
:
Wetland is important natural resource. The main method to monitor the landcover change in wetland natural reserve is to extract and analyze information from remote sensing image. In this paper, the landcover information is extracted, summarized and analyzed by using multi-temporal HJ and Landsat satellite image in Zhalong natural reserve, Heilongjiang, China. The method can monitor the wetland landcover change accurately in real time and long term. This paper expounds the natural factors and human factors influence on wetland land use type, for scientific and effective support for the development of the rational use of wetlands in Zhalong natural wetland reserve.
\end{abstract}

\section{INTRODUCTION}

The wetland is distributed all around the world. It possesses a lot of wildlife resources, which is one of the three ecological systems in the world with ocean and forest. The wetland has a powerful ecological purified effect, so it is also called "the kidney of the earth", which plays an important role in providing water resources, adjusting the climate, degrading the pollution, protecting the biodiversity and providing the resources for human production life. Under the pressure of the population explosion and economic development of the middle of the 20th century, a large number of wetland is transformed into farmland. With over exploitation and pollution, it leads to wetland area reduction, and the species of the wetland damaged, which arise the great attention of the society.

Heilongjiang Zhalong national wetland nature reserve is an important international wetland. It is a national rare waterfowl distribution area, especially for crane, and the biggest breeding colony of red-crowned crane in the world. Meanwhile it is also the most integrated, the most original, and the most expansively wetland ecosystem in the same latitude area of china. It is not only the paradise of bird survival and reproduction, but also can improve ecological environment and climatic conditions, prevent desertification of Songnen plain to the east, and adjust the climate of the dry sandstorm area of the west of Heilongjiang Province. At the same time, it plays an important part in increasing the yield of reed, improving the water quality and adding underground water. Since the 1960s, a lot of reservoirs have been built along the upstream of Zhalong wetland. Recently because of the drought and the increase of the Wuyuer River production and living, it leads to water shortage of Zhalong wetland reserve, ecological function and biodiversity declined, vegetation degeneration, the frequent fire, the wetland area reduced, which threaten the wetland ecological environment.
Since 2001, the government has launched an emergency project. In 2009, effective replenishment system was built, which remits the water shortage of Zhalong wetland reserve. Therefore, mastering the change of the earth surface has a profound effect on advancing the ecological environment, and maintaining the integration of the wetland and biodiversity.

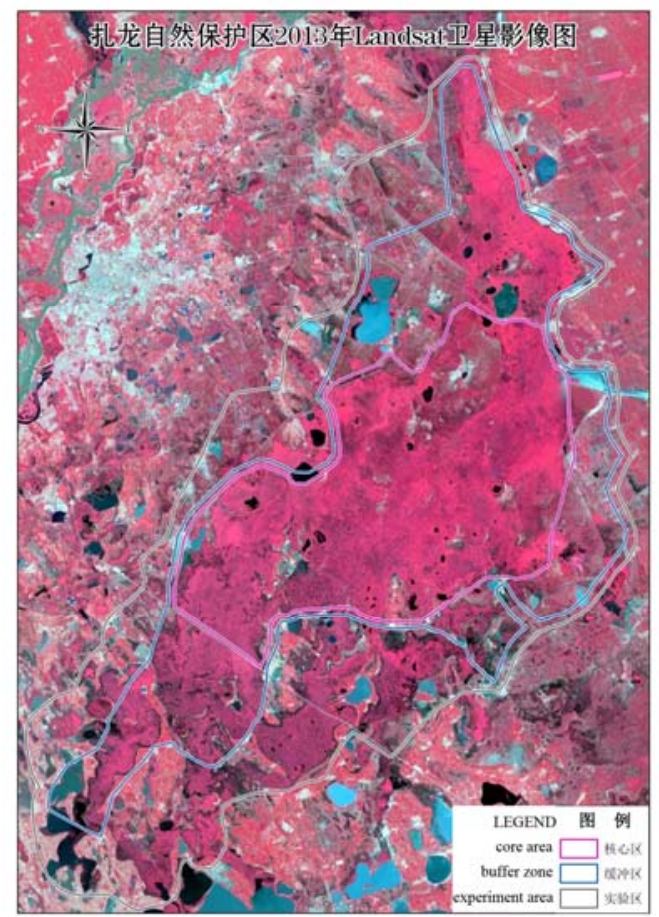

Figure 1. Landsat image of Zhalong wetland nature reserve in 2013

\section{EXPERIMENT AREA AND DATA}

Zhalong national wetland nature reserve is located in the west of Heilongjiang province, and it is wetland ecological system 
reserve. It is $80.94 \mathrm{~km}$ long and $58.34 \mathrm{~km}$ wide, which covers an area of $2253.27 \mathrm{~km}^{2}$, and the core area is $727.46 \mathrm{~km}^{2}$, the buffer zone is $686.84 \mathrm{~km}^{2}$, the experiment area is $838.97 \mathrm{~km}^{2}$. Zhalong wetland reserve is formed because of the overflow of the Wuyuer River. It consists of a lot of permanent seasonal fresh water wetland and a number of small shallow water. There are grass, farmland, and artificial fish pond around the wetland, which belongs to marsh wetland.

The article chooses the image from June to July in five years. The data is a compound of Landsat and HJ Satellite Images of Environmental Change. In order to make full use of the Landsat, and guarantee the accuracy and consistency, the program is as follows.

\begin{tabular}{cccc}
\hline $\begin{array}{c}\text { The main } \\
\text { image source }\end{array}$ & Time & Resolution & $\begin{array}{c}\text { Reference } \\
\text { Image }\end{array}$ \\
\hline LANDSAT & 2000.6 .28 & $30 \mathrm{~m}$ & \\
\hline LANDSAT & 2010.7 .2 & $30 \mathrm{~m}$ & \\
\hline HJ & 2011.7 .4 & $30 \mathrm{~m}$ & $\begin{array}{c}\text { LANDSAT } \\
(2011.8 .22)\end{array}$ \\
\hline HJ & 2012.7 .7 & $30 \mathrm{~m}$ & $\begin{array}{c}\text { LANDSAT } \\
(2012.7 .31)\end{array}$ \\
\hline LANDSAT & 2013.7 .10 & $30 \mathrm{~m}$ & \\
\hline
\end{tabular}

Table 1. Image data usage

\section{RESEARCH METHOD}

\subsection{Data Pre-processing}

Before extracting the information of land surface, we need geometric rectification and Image enhancement.(DANG Anrong, 2003) In order to optimize image data effect, we make an image transformation. (ZHAO Yingshi, 2003)
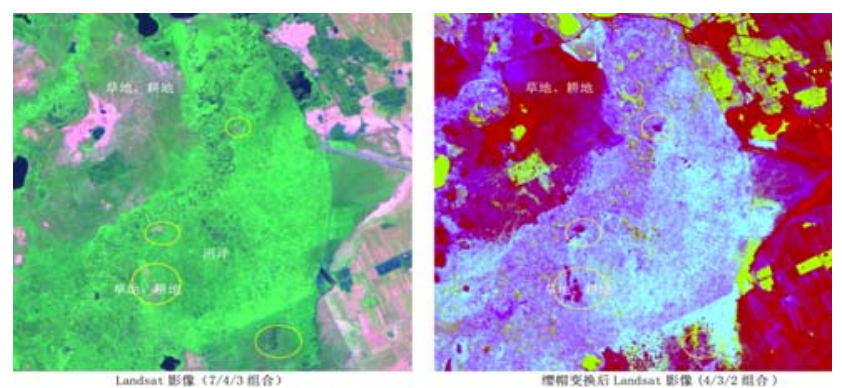

Figure 2. Image changes comparison of grassland, farmland and marshland
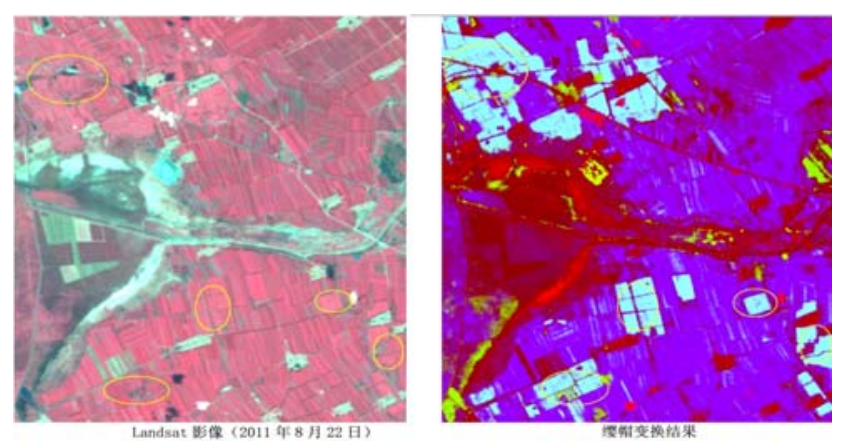

Figure 3. Image changes comparison of paddy field and dry land

\subsection{The Landcover Data Extraction}

According to the basic image data and monitor requirement, we are based on corrective satellite image and geographical conditions of census standard, the extraction is about farmland, grassland, marshland, construction site, salinealkali soil, unused land, water and so on.

\subsection{Statistical Summary}

The summary of the landcover data statistics is based on the DEM data of Zhalong wetland reserve, by basic statistical software for National Geographic Condition Survey (GDPJ, 2014) we make an accurate summary to five landcover classification data, which includes different kinds of area percentage.

The wetland surface of Zhalong wetland reserve is reed marsh wetland, which is composed of marshes, swamp meadow, the lake swamp. And lake swamp is fresh water lake.

According to the five years statistics results, the marsh area of 2013 is $1360.13 \mathrm{~km}^{2}$, which covers $60.36 \%$ of protection area, the agricultural acreage area is $340.28 \mathrm{~km}^{2}$, which covers $15.10 \%$; the grass area is $325.55 \mathrm{~km}^{2}$, which covers $14.45 \%$, the water area is $122.16 \mathrm{~km}^{2}$, which covers $5.42 \%$, the unused land is $58.36 \mathrm{~km}^{2}$, which covers $2.59 \%$, The construction area is $30.35 \mathrm{~km}^{2}$, which covers $1.35 \%$, the forest land is $16.44 \mathrm{~km}^{2}$, which covers $0.73 \%$. And the other area of marsh, water and grass is $80.32 \%$, which is in good condition. 


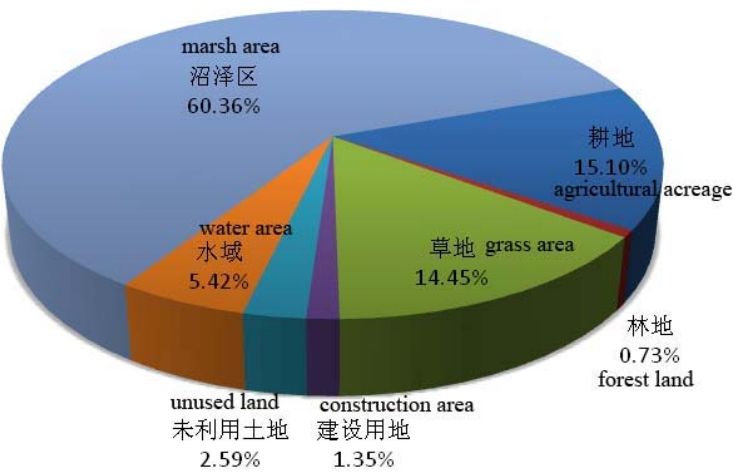

Figure 4. Landcover structure chart of Zhalong wetland reserve in 2013

\subsection{The Landcover Changes}

From 2000 to 2013, there are not too many changes of the landcover varieties. The marsh area is increased year by year while the unused area is declined .From the point of the types of landcover, it is mainly from grass and unused to marsh, which is in good condition.

Unit: square kilometre

\begin{tabular}{cccccc}
\hline \multirow{4}{*}{ TYPE } & Annual & Annual & Annual & Annual & Annual \\
& variation & variation & variation & variation & variation \\
& $2013-$ & $2010-$ & $2011-$ & $2012-$ & $2013-$ \\
2000 & 2000 & 2010 & 2011 & 2012 \\
\hline $\begin{array}{c}\text { agricultural } \\
\text { acreage }\end{array}$ & -0.10 & 0.01 & 8.54 & 5.89 & -15.82 \\
\hline
\end{tabular}

\begin{tabular}{cccccc}
\hline forest land & 0.11 & 0.23 & -0.76 & 0.21 & -0.31 \\
\hline
\end{tabular}

\begin{tabular}{cccccc}
\hline TYPE & $\mathbf{2 0 0 0}$ & $\mathbf{2 0 1 0}$ & $\mathbf{2 0 1 1}$ & $\mathbf{2 0 1 2}$ & $\mathbf{2 0 1 3}$ \\
\hline $\begin{array}{c}\text { agricultural } \\
\text { acreage }\end{array}$ & 341.57 & 341.67 & 350.21 & 356.10 & 340.28 \\
\hline forest land & 15.01 & 17.30 & 16.53 & 16.75 & 16.44 \\
\hline grass area & 473.30 & 449.74 & 467.96 & 427.18 & 325.55 \\
\hline $\begin{array}{c}\text { construction } \\
\text { area }\end{array}$ & 28.71 & 29.40 & 29.68 & 30.28 & 30.35 \\
\hline unused land & 110.18 & 91.22 & 77.93 & 73.47 & 58.36 \\
\hline water area & 112.67 & 112.52 & 102.07 & 104.43 & 122.16 \\
\hline marsh area & 1171.83 & 1211.42 & 1208.89 & 1245.06 & 1360.13 \\
\hline
\end{tabular}

Table 2. Landcover structure table of Zhalong wetland reserve in 2013

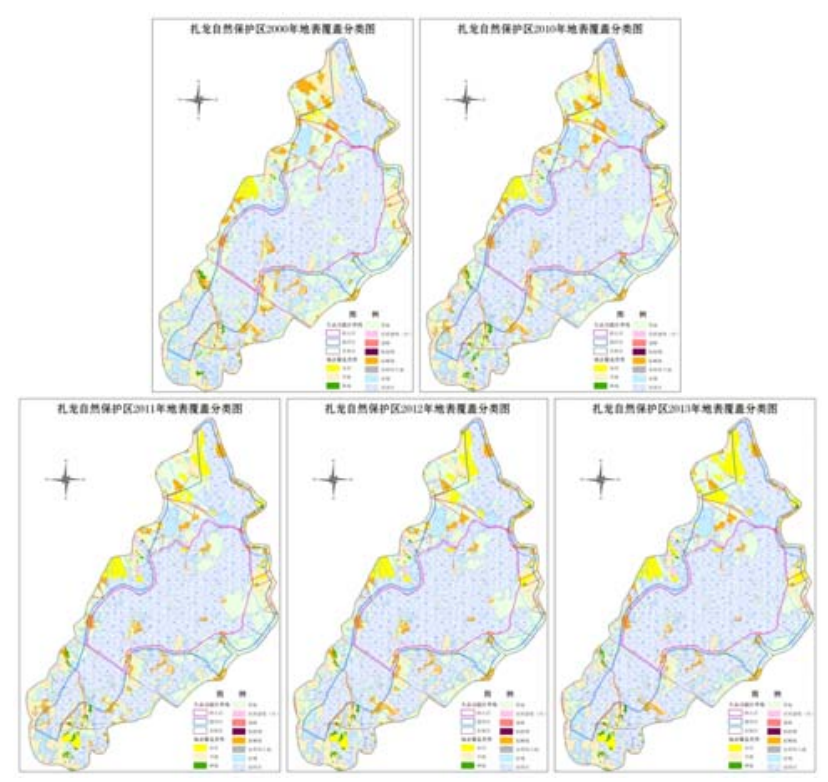

Figure 5. Classified landcover structure chart of Zhalong wentland reserve from 2000 to 2013

\section{ANALYSIS AND RESULTS}

\begin{tabular}{cccccc}
\hline grass area & -11.37 & -2.36 & 18.22 & -40.78 & -101.63 \\
\hline $\begin{array}{c}\text { construct- } \\
\text { ion area }\end{array}$ & 0.13 & 0.07 & 0.28 & 0.59 & 0.07
\end{tabular}

\begin{tabular}{llllll}
\hline unused land & -3.99 & -1.90 & -13.29 & -4.45 & -15.12 \\
\hline
\end{tabular}

$\begin{array}{lllllr}\text { water area } & 0.73 & -0.01 & -10.45 & 2.36 & 17.73\end{array}$

\begin{tabular}{llllll} 
Marsh area & 14.48 & 3.96 & -2.53 & 36.17 & 115.07 \\
\hline
\end{tabular}

Table 3. Landcover variation of Zhalong wetland reserve

According to the five years statistics results (2000, 2010, 2011, 2012, 2013), the changing characteristics are as follows.

- Farmland changes: the main change of the agricultural acreage between 2000 to 2013, is basically present first increase and slow decrease, especially 2012 to 2013, which declined 4.44\%. The main reason is because the large water area after replenishment makes the unused farmland drown, which in return becomes wetland again.

- Forest land changes: the forest land is in stable condition from 2000 to 2013.

- The grass changes: the main grass plant is pasture. From 2000 to 2013, the grass area changes a lot. Between 2012 to 2013, the area declined 23.79\%, while marsh and water area are increased obviously. This is due to the increase of the amount of precipitation from 2012 to 2013, the grass changes into reed swamp.

- The construction land changes: the construction land is in stable condition between 2000 to 2013.

- The unused land changes: the unused land in reserve is mainly saline-alkali soil. It is in stable condition and in a trend of decrease totally. It is mainly changed into grass and marsh land.

- Water changes: the water changes in first decrease and low increase trend from 2000 to 2013. And the water content is the lowest in 2011, which covers $4.53 \%$, and then the water content increases year by year.

- The marsh changes: from 2000 to 2013, It is obvious and in a good condition esp. between 2012 to 2013. Compared with 2012, it is increased by $115.07 \mathrm{~km}^{2}$. 


\subsection{Driving force analysis of nature}

The natural driving force of marsh wetland changes mainly includes climate factor and hydrological conditions. Rainfall of $400 \mathrm{~mm}$ for partial drought of Qiqihar region can be used as a standard watershed of precipitation. From 2000 to 2002, Qiqihar city is below $400 \mathrm{~mm}$ of precipitation, while the marsh wetland of Zhalong nature reserve severely shrunk. From 2009 to 2012, rainfall is basically above $500 \mathrm{~mm}$, in 2011, slightly less, marsh wetland area also increases accordingly.

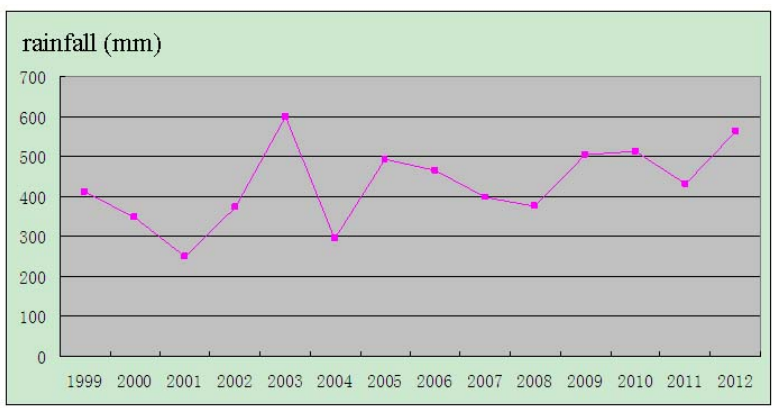

Figure 6. Rainfall of Qiqihar City from 1999 to 2012

\subsection{The Landcover Morphological Matrix Analysis}

Morphological Matrix is a main way to analyze the changes. The result indicates that from 2000 to 2010, the saline-alkali soil is changed into grass and marshland, and the grass is changed into marsh and saline-alkali soil. Because of the waterfall, the grass is mainly changed into marsh, and most of the unused land is changed into marshland, which accords with regular rules.

From 2000 to 2013, the number of landcover is large, mainly because the farmland changes into grassland, and grassland transforms into marshland, which indicates the good trend of ecological development in reserve. The increase of grassland is mainly due to the grazing prohibition policy, which has the grassland recovered.

Unit: square kilometre

\begin{tabular}{ccccccccc}
\hline \multirow{2}{*}{ TYPE } & \multicolumn{1}{c}{$\begin{array}{c}\text { agricultur- forest } \\
\text { al acreage }\end{array}$} & land & area & construct- & ion area & land & area & area \\
\hline $\begin{array}{c}\text { agricultural } \\
\text { acreage }\end{array}$ & 294.66 & 4.84 & 18.22 & 1.00 & 3.42 & 1.32 & 18.13 \\
\hline forest land & 2.90 & 10.75 & 1.32 & 0.00 & 0.02 & 0.00 & 0.02 \\
\hline grass area & 23.09 & 0.64 & 225.1 & 0.45 & 13.98 & 6.89 & 203.19 \\
\hline $\begin{array}{c}\text { construct- } \\
\text { ion area }\end{array}$ & 0.20 & 0.00 & 0.22 & 27.88 & 0.01 & 0.29 & 0.12 \\
\hline unused land & 2.46 & 0.09 & 42.22 & 0.74 & 39.56 & 5.50 & 19.65 \\
\hline water area & 0.89 & 0.01 & 0.58 & 0.00 & 0.21 & 94.25 & 16.76 \\
\hline marsh area & 16.11 & 0.12 & 37.91 & 0.29 & 1.17 & 13.94 & 1102.5 \\
\hline
\end{tabular}

Table 4. Data transfer sketch map from 2000 to 2013

\subsection{Landscape Pattern Analysis}

The project uses fragstas software to analyze the changes of Zhalong wetland reserve by calculating the landscape pattern index. The number of patch and patch density of landscape is declined as time goes by, which indicate interference is under control. The landscape isolation doesn't change a lot, and the wetland landscape doesn't influence a lot by human beings. The decline of the landscape diversity index and the rise of dominance index doesn't change a lot, which indicate the stable pattern doesn't influenced a lot by human beings.

\begin{tabular}{|l|l|l|l|l|l|}
\hline \multirow{2}{*}{ Index } & \multicolumn{5}{|c|}{ Value of different years } \\
\cline { 2 - 6 } & 2000 & 2010 & 2011 & 2012 & 2013 \\
\hline $\begin{array}{l}\text { Landscape } \\
\text { area }\end{array}$ & \multicolumn{5}{|c|}{225364.98 (ha) } \\
\hline patch density & 0.5662 & 0.5573 & 0.5161 & 0.5094 & 0.5036 \\
\hline $\begin{array}{l}\text { number of } \\
\text { patch }\end{array}$ & 1276 & 1256 & 1163 & 1148 & 1135 \\
\hline $\begin{array}{l}\text { maximum } \\
\text { patch }\end{array}$ & 31.9726 & 32.7110 & 32.5276 & 33.5856 & 36.0430 \\
\hline $\begin{array}{l}\text { average } \\
\text { dimension }\end{array}$ & 1.1723 & 1.1701 & 1.1657 & 1.1666 & 1.1646 \\
\hline $\begin{array}{l}\text { landscape } \\
\text { isolation }\end{array}$ & 66.4415 & 68.0271 & 67.9069 & 67.6435 & 68.8562 \\
\hline $\begin{array}{l}\text { landscape } \\
\text { diversity }\end{array}$ & 1.3916 & 1.3820 & 1.3840 & 1.3713 & 1.3158 \\
\hline $\begin{array}{l}\text { landscape } \\
\text { evenness }\end{array}$ & 0.5804 & 0.5763 & 0.5772 & 0.5719 & 0.5487 \\
\hline $\begin{array}{l}\text { landscape } \\
\text { dominance }\end{array}$ & 0.7186 & 0.7236 & 0.7225 & 0.7292 & 0.7560 \\
\hline $\begin{array}{l}\text { landscape } \\
\text { fragmentation }\end{array}$ & 0.0057 & 0.0056 & 0.0052 & 0.0051 & 0.0050 \\
\hline
\end{tabular}

Table 5. Landscape structure changes from 2000 to 2013

\section{CONCLUSION}

1.From the result of landcover statistics, Zhalong wetland reserve is mainly covered with marsh, grass and water whose areas are about $80.23 \%$ in 2013.

2.Between 2000 and 2013, the vegetation area of land surface didn't change a lot. The grass area is reduced by $34 \%$, and the saline-alkali soil $54 \%$, which are transformed into marshland whose area is increased by $17 \%$. The area of farmland and construction is increased a little, which is distributed in experiment area. All these indicate that the effective measures have been taken in the reserve.

3.From the changing situation of landcover, the condition is improved and the marshland is recovering which is in a stable stage. The effective replenishment guarantees the stable growth of the reed swamp. 
Under the deterioration of the environment, the function and benefit of wetland play an increasingly important role. And the evaluation system is various.

The article reflects the development process from the landcover variation, the landcover morphological matrix analysis, and landscape pattern analysis. Relative research data and reports provide basic data for Zhalong environment protection and exploitation of natural resources. The dynamic monitor to the key ecological function area gives support to the government on the overall project and relative decision.

\section{REFERENCES}

DANG Anrong, W., 2003. ERDAS IMAGE - Methods of Remote sensing image processing, Tsinghua University Press, Beijing, pp. 116-123.

ZHAO Yingshi, 2003, Analysis principle and method of remote sensing applications, Science Press, Beijing, pp.183194

GDPJ, 2014. Contents and indicators of National Geographic Condition Survey, Beijing ,China, GDPJ 01-2013, pp.

LI Ying, T., 2003. Driving Forces Analysis of Mire Wetland Change in Lower Nenjiang Watershed. In: Scientia Geographica Sinica, Beijing, China, Vol. XXIII, pp. 686-691. 